\title{
SEX EDUCATION "KEKERASAN SEKSUAL PADA ANAK" UPAYA PREVENTIF TINDAK KEKERASAN DAN PELECEHAN SEKSUAL PADA ANAK
}

\author{
Paul Joae Brett Nito ${ }^{1 *}$, Umi Hanik Fetriyah ${ }^{2}$, Malisa Ariani ${ }^{3}$ \\ 1,2,3Program Studi Sarjana Keperawatan, Fakultas Kesehatan, \\ Universitas Sari Mulia, Banjarmasin, Kalimantan Selatan \\ ${ }^{*}$ Email: pauljbn91@yahoo.co.id
}

\begin{abstract}
ABSTRAK
Kekerasan seksual pada anak sering terjadi karena kurangnya pencegahan yang dilakukan. Komisi Perlindungan Anak Indonesia (KPAI) melansir ada 123 kasus kekerasan seksual anak di sekolah pada tahun 2019. Meningkatnya angka kejadian kekerasan seksual pada anak menjadi perhatian khusus setiap negara. Karena itu perlu upaya pencegahan, salah satunya adalah peningkatan pengetahuan melalui pendidikan kesehatan seksual. Kegiatan ini memberikan edukasi kepada siswa sekolah dasar untuk meningkatkan pengetahuan siswa sebagai upaya preventif kekerasan seksual. Tujuan kegiatan adalah tercapainya peningkatan pengetahuan tentang kekerasan seksual. Metode yang digunakan adalah memberikan Pendidikan Kesehatan yang dilakukan sebanyak tiga kali dengan materi 1) Definisi dan Bentuk Kekerasan Seksual, 2) Dampak Kekerasan Seksual, 3) Apa yang harus dilakukan. Hasil kegiatan menunjukkan peningkatan pengetahuan peserta dengan nilai rata-rata adalah 67,78. Program seks edukasi harus terus dilanjutkan untuk meningkatkan pengetahuan dan kesadaran siswa tentang kekerasan seksual untuk mencegah terjadinya kekerasan seksual.
\end{abstract}

Kata kunci: Seks Edukasi, Kekerasan seksual, Pendidikan Kesehatan

\section{A. PENDAHULUAN}

Catatan Komisi Perlindungan Anak Indonesia (KPAI) pada tahun 2010-2015 terdapat 21,6 juta kasus. Tahun 2019, tercatat 21 kasus kekerasan seksual (korban mencapai 123 anak) terjadi di institusi pendidikan. Lembaga Perlindungan Saksi dan Korban (LPSK), menyebutkan terdapat 350 perkara kekerasan seksual pada anak ditahun 2019 (Fitriani D dkk, 2021). Kelemahan fisik dan ketergantungan anak terhadap orang dewasa menjadi salah satu faktor meningkatnya kejadian kekerasan seksual pada anak (Utami DRRB dkk, 2018).

UNICEF (2018) menyebutkan bahwa 1 dari 10 anak di dunia mengalami kekerasan terutama perempuan. Meningkatnya angka kejadian kekerasan seksual pada anak menjadikan perhatian diseluruh dunia akan pentingnya tindakan pencegahan diterapkan untuk mencegah kekerasan seksual pada anak. WHO menyebutkan bahwa kekerasan seksual pada anak 
menjadi masalah di seluruh dunia (Darma DD dkk, 2021). Meningkatnya angka kejadian pelecehan seksual pada anak memberikan signal kepada pihak terlibat bahwa pentingnya pengetahuan, sikap dan perilaku untuk mencegah terjadinya pelecehan seksual pada anak (Andari ID et al, 2019).

Upaya preventif yang dapat dilakukan adalah pemberian edukasi terkait seksual. SDG's, melalui program Comprehensive Sexuality Education (CSE) menjadi salah satu strategi untuk menjamin anak mendapat pendidikan dan kesetaran dalam memahami perilaku seks sebagai pencegahan yang memuat salah satunya adalah aktivitas seksual berisiko, dan dengan tujuan pencegahan dari kejahatan seksual (Tjomiadi CEF dkk, 2021; Nito PJB dkk, 2021).

Informasi seksualitas yang tepat dapat digunakan anak pada tahap perkembangan selanjutnya sebagai panduan anak terkait seksualitas (Perry et al, 2014; Utami DRRB dkk, 2018). Melalui Pendidikan seksual yang diberikan, membantu anak-anak berpikir seks secara lebih bermakna (Andari ID et al, 2019; Kantor L \& Levitz N, 2017).
Pendidikan seksual merupakan salah satu hak anak, wajib diberikan sedini mungkin sesuai perkembangan anak. Pendidikan seksual memberikan informasi-informasi yang diperlukan anak untuk membantu anak dalam mengambil tanggung jawab atas kesehatan dan kesejahteraan seksualitasnya (Banegas et al, 2020). Pendidikan seksual merupakan upaya yang dilakukan untuk meningkatkan pengetahuan seksualitas individu. Kurangnya pengetahuan anak ataupun individu tentang seksual memberikan dampak buruk, misalnya meningkatnya perilaku seksual beresiko, penyimpangan seksual, pelecehan seksual dan seks bebas (Pradikto B \& Sofino, 2019).

Pendidikan seksual sejak dini merupakan salah satu strategi pencegahan kejadian kekerasan seksual pada anak. Pendidikan seksual yang diberikan tentu harus mempertimbangkan usia dan tahap perkembangan anak, dengan tujuan agar anak mendapatkan informasi yang tepat, mampu beradaptasi dan bertindak terhadap permasalahan seksual yang mereka hadapi, serta terhindar menjadi korban kejahatan seksual (Perry et al, 2014; Fitriani D dkk, 2021). 
Berdasarkan hasil analisis kondisi pada penduduk yang terletak di pinggiran kota Banjarmasin didapatkan bahwa kurangnya informasi mengenai kekerasan seksual, kurangnya waktu orang tua dalam mengontrol dan memberi edukasi anak karena kesibukkan rutinitas kerja. Pihak sekolah di lokasi pengabdian menyatakan bahwa selama ini pendidikan seksual yang diberikan kepada peserta didik belum optimal. Berdasarkan hasil observasi diperoleh informasi bahwa minimnya pemberian edukasi tentang seks di SD kota Banjarmasin. Berdasarkan hal tersebut, sangat penting diberikannya pengetahuan tentang seksual anak sebagai salah satu cara pencegahan terjadinya kekerasan seksual pada anak (Fatmawati dan Nurpiana, 2018). Tujuan dan manfaat pada pengabdian ini adalah untuk meningkatkan pengetahuan dan pemahaman anak SD tentang kekerasan seksual.

\section{B. METODE}

Mitra pada kegiatan pengabdian masyarakat ini adalah SD Islami Rahmatillah Wilayah Banjarmasin Timur. Solusi untuk mengatasi situasi terkait pencegahan kekerasan seksual pada anak dilakukan dengan tiga langkah yaitu:

1) Pendidikan kesehatan. Pendidikan kesehatan dilakukan tiga kali. Target kegiatan ini adalah 18 peserta. Pada pendidikan kesehatan pertama, kegiatan berupa pendidikan kesehatan oleh mahasiswa selama 30 menit dan diikuti sesi tanya jawab selama 15 menit. Pemberian materi diberikan melalui media power point, dan setiap peserta diberikan poster yang berisi informasi tentang definisi dan Bentuk Kekerasan Seksual.

2) Pendidikan kesehatan kedua dilakukan dengan kegiatan berupa pendidikan kesehatan oleh mahasiswa selama 30 menit dan diikuti sesi tanya jawab selama 15 menit melalui media power point, dan setiap peserta diberikan poster yang berisi informasi tentang dampak kekerasan seksual.

3) Pendidikan kesehatan ketiga dilakukan dengan kegiatan pendidikan kesehatan oleh mahasiswa selama kurang lebih 30 menit dan diikuti sesi tanya jawab selama 15 menit melalui media power point yang berisi informasi tentang apa yang harus dilakukan.

Pre dan post test dilakukan untuk menilai pengetahuan peserta. 
Kelompok mitra pada kegiatan ini adalah siswa SD di wilayah Banjarmasin Timur. Mitra dilibatkan dalam pelaksanaan kegiatan pendidikan Kesehatan, dengan berpartisipasi aktif dan menyediakan tempat serta fasilitas. Mitra juga terlibat dalam penyebaran informasi kepada orang tua peserta sesuai dengan yang ditargetkan. Indikator keberhasilan adalah peserta mengetahui definisi dan bentuk kekerasan seksual; dampak kekerasan seksual; dan apa yang harus dilakukan.

Gambar 1.1 Alur Pengabdian Kepada Masyarakat di SD Islami Rahmatillah wilayah Banjarmasin Timur

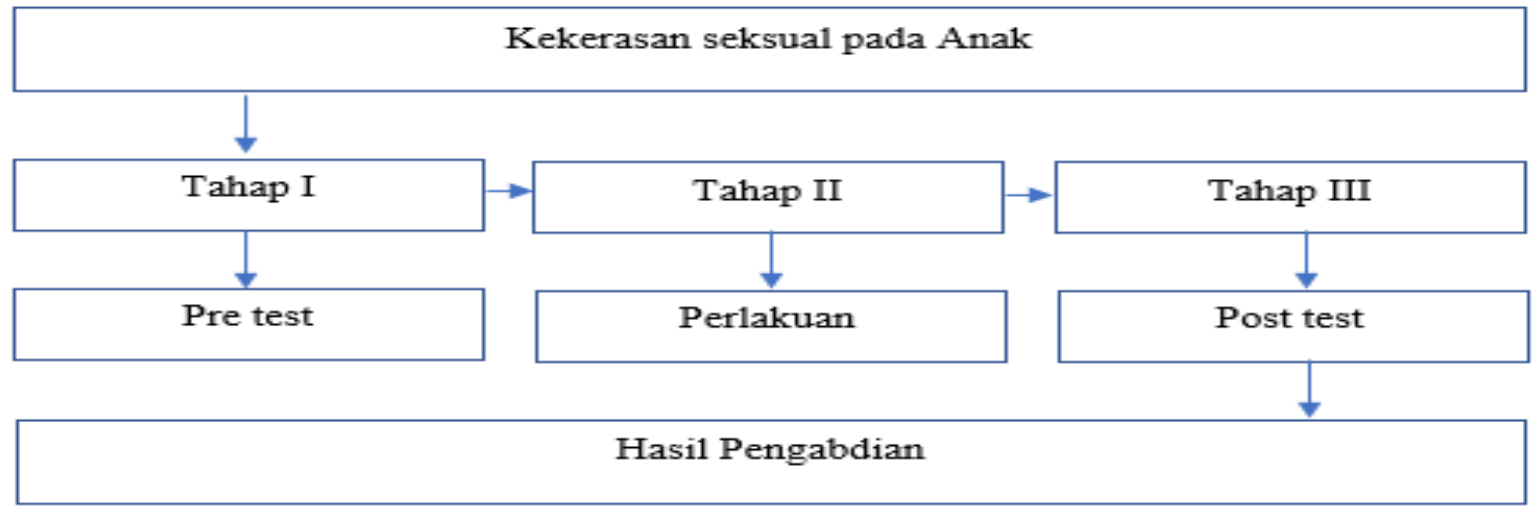

Gambar 1.2 Kegiatan Pengabdian Masyarakat
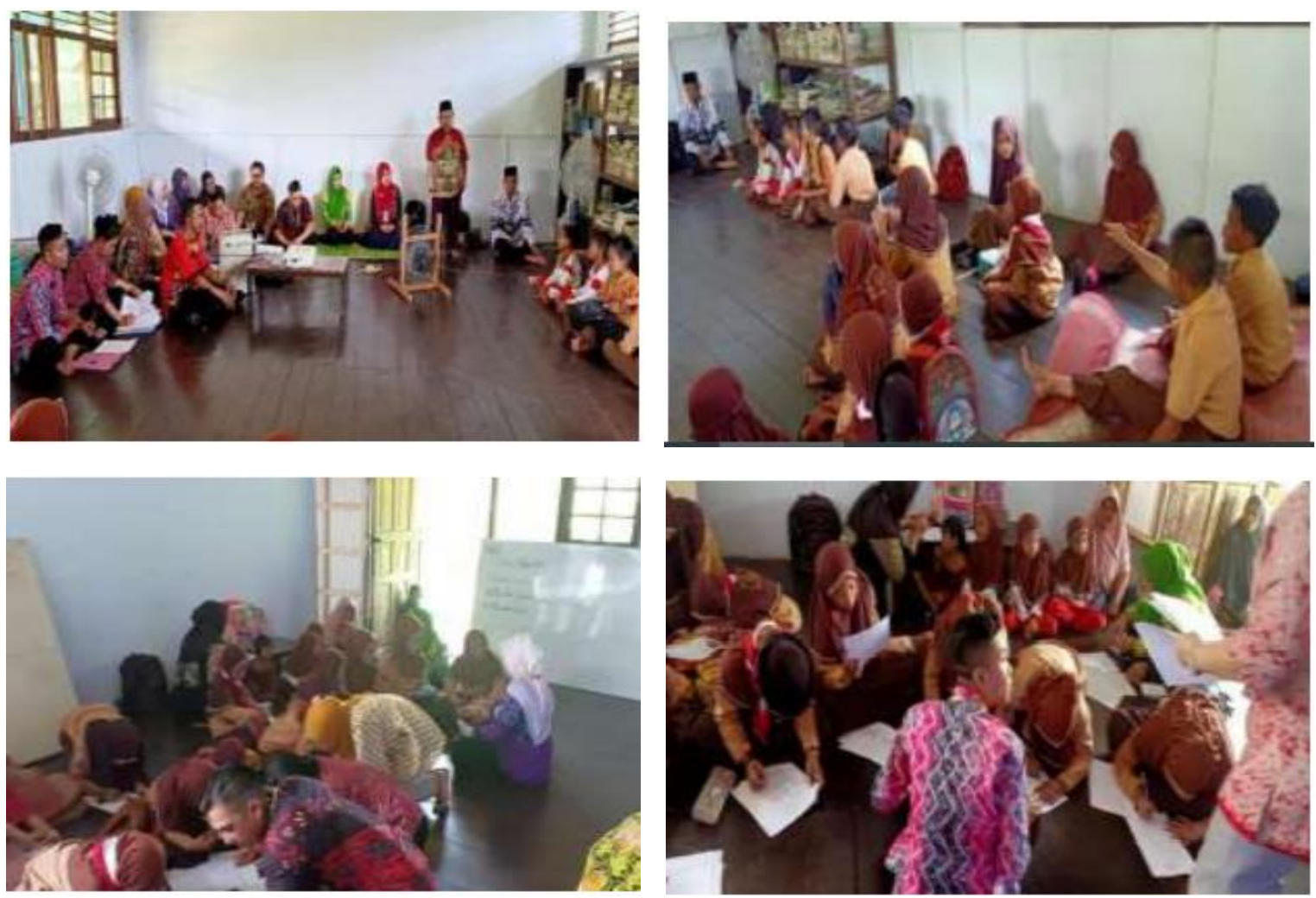


\section{HASIL DAN PEMBAHASAN}

Kegiatan Pendidikan Kesehatan Seksual terdiri dari definisi dan bentuk kekerasan seksual; dampak kekerasan seksual; dan apa yang harus dilakuakn berjalan dengan lancar. Kegiatan dihadiri oleh siswa SD dan pengurus sekolah. Peserta menunjukkan antusiasme sepanjang program dilaksanakan. Jumlah peserta penyuluhan yang menghadiri sebanyak 18 peserta (siswa). Pihak sekolah ikut serta dalam kegiatan. Kerjasama yang dilakukan antara tim pelaksana dan pengurus sekolah terjalin dengan baik. Hal ini menjadi salah satu faktor utama keberhasilan dan antusiasme peserta selama kegiatan berlangsung. Kegiatan pendidikan kesehatan seksual yang sudah dilakukan menghasilkan produk berupa poster keketrasan seksual pada anak. Selama kegiatan pendidikan kesehatan pertama, kedua, dan ketiga terlihat antusiasme peserta dalam mendengarkan materi yang diberikan. Saat sesi tanya jawab terdapat 2 peserta yang bertanya, dan 5 peserta mampu menjawab pertanyaan dari panitia.

Pihak sekolah yang terdiri dari kepala sekolah dan perwakilan guru berterima kasih dengan kegiatan pendidikan kesehatan seksual yang telah dilaksanakan di sekolah. Pihak sekolah berpendapat bahwa pendidikan kesehatan seksual untuk anak usia sekolah selama masih minim dan tidak pernah didapatkan secara langsung dari pihak institusi kesehatan, sehingga kegiatan yang telah dilakukan panitia sangat bermanfaat. Selama kegiatan panitia menyadari masih terdapat kekurangan, dimana panitia belum dapat memenuhi sasaran yang diharapkan, yaitu hadirnya orang tua dalam kegiatan. Kehadiran orang tua sebenarnya sangat diharapkan panitia, karena orang tua juga perlu memahami kekerasan seksual pada anak sebagai upaya preventif yang dapat dilakukan orang tua.

Hasil penelitian yang telah dilakukan oleh Utami DRRB dkk (2018) dan penelitian Amalia E dkk (2018) menyebutkan hasil statistik bahwa pendidikan seksual berpengaruh secara signifikan terhadap tingkat pengetahuan anak tentang kekerasan seksual. Pendidikan Kesehatan diberikan melalui metode pengajaran berupa penyampaian materi yang diintegrasikan dengan diskusi interaktif, gerakkan atau simulasi, story ytelling, dan video. Edukasi yang diberikan meningkatkan pengetahuan anak tentang kekerasan seksual. Pengetahuan individu atau anak diharapkan dapat 
menjadi pegangan anak dalam menghindari kekerasan seksual. Selain itu, anak dapat bertindak tepat terhadap situasi yang memungkinkan terjadinya kekerasan seksual.

Pendidikan seksual sejak dini memiliki peranan penting dalam upaya pencegahan kejadian kekerasan seksual pada anak. Hasil penelitian Ikhwanisifa dkk (2019) dengan menggunakan metode pembelajaran play therapy, didapatkan bahwa sisa mengalami peningkatan kemampuan dan pengetahuan dalam menghadapi kekerasan seksual. Peneliti menyebutkan, siswa mampu mencari bantuan pada orang lain, dan peningkatan dalam menolong diri sendiri sehingga individu tidak hanya diam saat mengalami kekerasan seksual. Hasil penelitian ini sesuai dengan salah satu tujuan pengabdian masyarakat yang dilakukan, yaitu anak mampu menentukan harus melakukan apa jika terjadi situasi yang mengarah kepada kekerasan seksual.

Tingkat pengetahuan peserta pendidikan seksual yang berjumlah 18 siswa mengalami peningkatan. Hal ini tergambarkan dari hasil pre dan post test yang telah dilakukan selama kegiatan berlangsung.

\section{Gambar 1.3 Rata-rata Pre dan Post Test Tingkat Pengetahuan Siswa tentang Kekerasan Seksual}

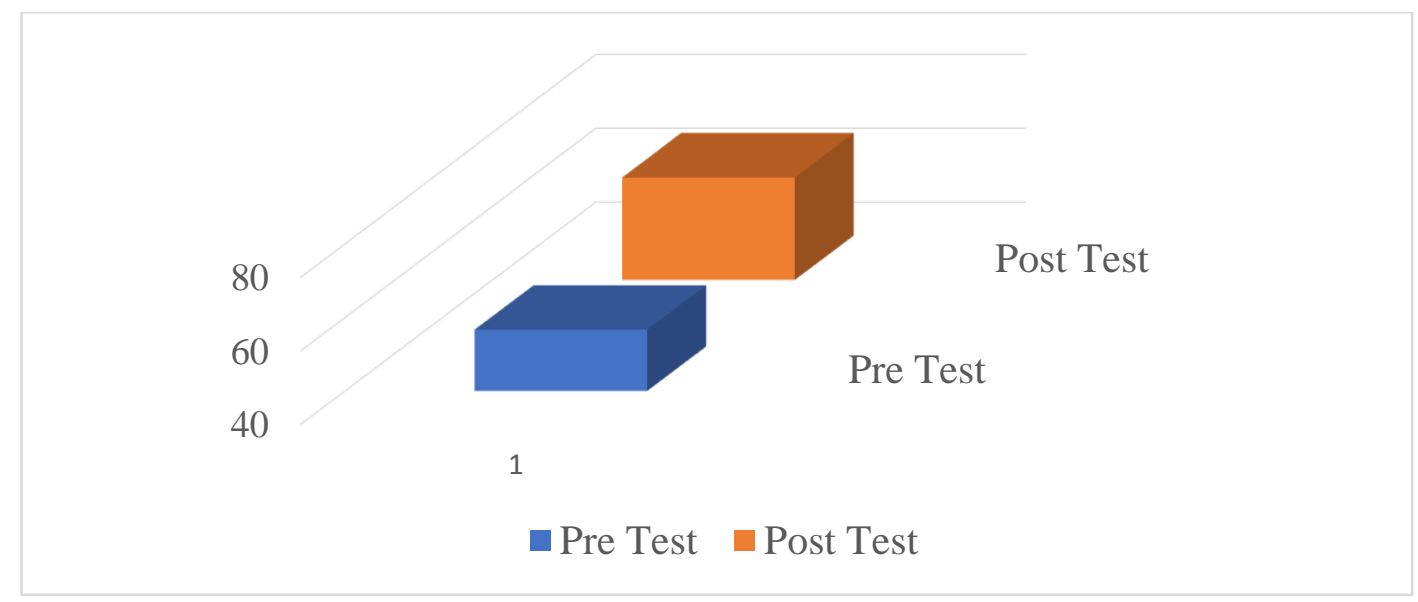

Berdasarkan gambar 2 rata-rata pre dan post test tingkat pengetahuan siswa tentang pendidikan seksual mengalami peningkatan. Sebelum pendidikan seksual diberikan, rata-rata pengetahuan siswa adalah 56,67 dengan nilai terendah 30 dan nilai tertinggi adalah 80. Setelah diberikan 
pendidikan seksual, rata-rata pengetahuan siswa adalah 67,78 dengan nilai terendah adalah 50 dan nilai tertinggi adalah 100 .

Hasil pre dan post test menyimpulkan bahwa terdapat dampak positif dari kegiatan pendidikan seksual yang telah dilakukan. Hal ini sesuai dengan hasil penelitian Darusmin DF (2020) yang dilakukan terhadap 84 siswa menggunakan metode pembelajaran active joyfull learning (AJEL), didapatkan bahwa terdapat peningkatan pengetahuan dan pemahaman siswa mengenai tubuhnya, menjaga tubuhnya, dan memahami sentuhan aman dan tidak aman.

Hasil ini juga sejalan dengan hasil penelitian yang dilakukan oleh Margaretta SS dan Kristyaningsih $\mathrm{P}$ (2020), yang menyebutkan bahwa terdapat pengaruh pendidikan seksual terhadap pengetahuan seksualitas dan cara pencegahan kekerasan seksual anak usia sekolah. Peneliti menggunakan media video animasi denhgan menggunakan karakter animasi guru dan siswa/i dengan durasi 6 menit.

Hasil penelitian Vidayanti V dkk (2020) juga memiliki hasil yang sama, dimana terdapat peningkatan pengetahuan siswa sebelum dan sesudah diberikan pendidikan seksual dengan rata rata pengetahuan sebelum intervensi 74,78 dan sesudah intervensi 82,86. Penelitian Darma DD dkk (2021) juga menghasilkan kesimpulan bahwa media bergambar sebagai media pendidikan seksual mampu meningkatkan pengetahuan siswa tentang pencegahan kekerasan seksual pada anak.

\section{KESIMPULAN}

Kegiatan pengabdian pada masyarakat ini memberi pengetahuan kepada siswa SD mengenai pencegahan kekerasan seksual pada anak melalui materi kesehatan seksual tentang definisi dan bentuk kekerasan seksual; dampak kekerasan seksual; dan apa yang harus dilakukan. Pelaksanaan pendidikan kesehatan memberikan dampak terhadap peningkatan pengetahuan tentang pencegahan kekerasan seksual pada anak. Tim pengabdian berharap, kedepannya kegiatan pengabdian masyarakat berlanjut dengan memberikan program pendidikan seksual berdasarkan tingkat perkembangan anak, dan melibatkan orang tua sebagai sasaran. 


\section{DAFTAR PUSTAKA}

Andari ID, Woro O, Yuniastuti A. (2019). The Effect of Knowledge, Attitude, and Parents Behavior Towards Sex Education Parents With Sexual Violence Incident. Public Health Perspectives Journal, 4 (2): 141-148.

Amalia E., Afdila FL., dan Andriani Y. (2018). Pengaruh Pemberian Pendidikan Seksual Terhadap Kejadian Kekerasan Seksual Pada Anak Di SD Negeri 04 Balai Rupih Simalanggang Payakumbuh Tahun 2018. Jurnal Kesehatan Perintis (Perintis's Health Journal), 5(2): 188-194.

Banegas, Darío Luis, \& Lauze, Cristina. (2020). CLIL and Comprehensive Sexual Education: A Case of Innovation From Argentina. Profile Issues in Teachers' Professional Development, 22(2), 199-209. Epub August 2020. https://dx.doi.org/10.15446/profile. v22n2.80528

Darma DD., Asmawati., dan Efendi P. (2021). Pengaruh Media Bergambar Terhadap Pengetahuan Dan Sikap Pencegahan Kekerasan Seksual Pada Siswa Sekolah Dasar. Jurnal Penelitian Terapan Kesehatan, 8(1): 1-39.

Darusmin DF. (2020). “Aku Dan Tubuhku: Efektifitas Program Pengenalan Tubuh Dengan Prinsip "Active Joyfull Learning" (AJEL) Sebagai Salah Satu
Tindakan Pencegahan Tindakan Pelecehan Dan Kekerasan Seksual Pada Anak. Consilia Jurnal Ilmiah BK, 3(1): 55-66.

Fatmawati dan Nurpiana. (2018). Pengetahuan Orang Tua Tentang Pendidikan Seks Pada Anak Usia Dini. Jurnal Ilmiah Kesehatan Iqra, 6 (2): 77-83.

Fitriani D., Fajriah H., dan Wardani A. (2021). Mengenalkan Pendidikan Seks Pada Anak Usia Dini Melalui Buku Lift The Flap “Auratku". Gender Equality: International Journal of Child and Gender Studies, 7(1): 33-46.

Ikhwanisifa., Raudatussalamah., dan Susanti R. (2019). Islamic Group Play Therapy: Upaya Pengembangan Keterampilan Help Seeking Behaviour Dalam Menghadapi Kekerasan Seksual Pada Anak. Generasi Emas Jurnal Pendidikan Islam Anak Usia Dini, 2(2): 108-115.

Kantor L dan Levitz N. (2017). Parent's view on sex education in schools: How much do Democrats and Republicans agree?. PLOS ONE, 2(7): e0180250. https://doi.org/10.1371/journal.pon e. 0180250

Margaretta SS. (2020). Effektifitas Edukasi Seksual Terhadap Pengetahuan Seksualitas Dan Cara Pencegahan Kekerasan Seksual Pada Anak Usia Sekolah. Prosiding Seminar Hasil penelitian. IIKBW PRESS: 567-61. 
Nito PJB., Tjomiadi CEF., Manto OAD. (2021).

Hubungan Jenis Kelamin Dengan

Tingkat Pengetahuan Comprehensive Sexuality Education (CSE) Pada

Mahasiswa. Dinamika Kesehatan:

Jurnal Kebidanan Dan Keperawatan, 12(2).

Perry, S. E., Hockenberry, M., Lowdermilk, \& Wilson, D. L. (2014). Maternal Child Nursing Care. (K. Cashion \& Alden, Eds.). St Louis Missouri: Elsevier.

Pradikto B \& Sofino. (2019). Sex Education in Family: Study on Children Living Far Apart with The Family. Journal of Nonformal Education, 5 (2): 132137. DOI: http://dx.doi.org/10.15294/jne.v5i2. $\underline{20786}$

Tjomiadi CEF., Nito PJB, Manto OAD. (2021). Comprehensive Sexuality education (CSE) of Adolescent in Higher Education: Identification of First Year Students' Knowledge of CSE in an effort to Improve Sexual and Reproductive Health.
International Conference on Health Science, 1(1): 611-620.

UNESCO. (2018). International technical guidance on sexuality education: an evidence-informed approach $(P D F)$. Paris: UNESCO, 15-80. ISBN 978-92-3-100259-5. https://unesdoc.unesco.org/ark:/482 23/pf0000260770

Utami DRRB., Susilowati T. (2020). Program “Aku Mandiri” Sebagai Upaya Pencegahan Kekerasan Seksual Pada Anak Usia Pra Sekolah. GASTER, 16(2): 127-137. Vidayanti V., Tungkaki KTP., Retnaningsih LN. (2020). Pengaruh Pendidikan Seks Dini melalui Media Video Animasi terhadap Peningkatan Pengetahuan Anak Usia Sekolah tentang Seksualitas di SDN Mustokorejo Yogyakarta. Jurnal Formil (Forum Ilmiah) KesMas Respati, 5(2): 203-214. 